\title{
Arbitration of
}

\section{Employment-discrimination}

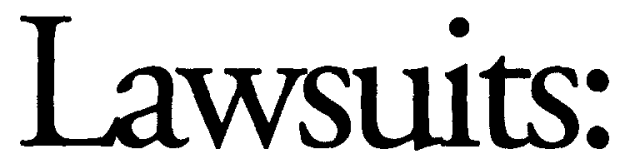

\section{Legalities, Practicalities, and Realities}

\begin{abstract}
Arbitration agreements can be an effective, cost-effective way to settle employment disputesbut not all courts agree about what constitutes an enforceable contract.
\end{abstract}

BY DAVID SHERWYN

$\mathrm{P}$ re-dispute mandatory arbitration of employmentrelated lawsuits is the centerpiece of numerous hospitality employers' employee-relations programs. Companies as diverse as Four Seasons, Darden Restaurants, and Waffle House have implemented such programs to avoid the time, expense, and ill will that are inherent in the litigation process. Employers who have implemented mandatoryarbitration policies proudly report that the programs have been successful from both the employers' and employees' perspectives. ${ }^{1}$ Notwithstanding such positive reviews, academics, legislators, and employee-rights advocates have made attacking mandatory arbitration a cottage industry. Even the popular press has come out against mandatory arbitration.

\footnotetext{
${ }^{1}$ Interviews with in-house counsel for Halliburton and Darden Restaurants, and vice president of human resources for Four Seasons.
}

In contrast, the courts have, for the most part, been friendly to mandatory arbitration even though the law of arbitration has been unsettled since 1991. In the last two years, however, there have been two U.S. Supreme Court and at least four circuit-court cases that have clarified the law and made it clear that employers can implement such policies as a term and condition of employment. The purpose of this article is to explain the law pertaining to mandatory arbitration. Before discussing arbitration's legality, however, it is necessary to explain why a growing number of employers consider mandatory arbitration a sound policy.

Why Employers Choose Arbitration

The short answer to why employers seek arbitration is the cost of litigation. Employment-discrimination suits are a

(C) 2002, CORNELL UNIVERSITY 
growth industry in the United States. In 1989 employees filed 63,898 discrimination claims with the EEOC; in 2001 employees filed 80,840 discrimination charges, a 26-percent increase in 10 years. $^{2}$ Furthermore, those numbers underrepresent the actual number of discrimination claims, because employees file a similar number of claims with affiliated state and local agencies. It is not, however, the number of legitimate claims that trouble employers. Instead, it is the expense of the process, the number of frivolous claims, and the perverse incentives inherent in this adjudication process that leads employers and employees alike to conclude that the system is broken.

To file a discrimination lawsuit, employees must first file a charge of discrimination with the EEOC or an affiliated state agency. ${ }^{3}$ The EEOC has almost always tried to convince the parties to settle. If the parties do not settle at its prompting, the EEOC investigates the claim and renders its opinion as to whether there is "reasonable cause" to believe that the plaintiff has been discriminated against. ${ }^{4}$ Regardless of whether the EEOC "finds cause," the agency then issues a "right to sue" letter. ${ }^{5}$ This letter "allows" the plaintiff to file a claim in federal court. In an extraordinarily small percentage of the cases filed, the EEOC decides that the issue is so important that the agency should litigate on the plaintiff's behalf.

\footnotetext{
${ }^{2}$ See: "U.S. Equal Employment Opportunity Comm'n, Enforcement Statistics FY 1986-1996 (May 1997)" and "U.S. Equal Employment Opportunity Comm'n, Enforcement Statistics FY 2001," at www.eeoc.gov.
}

${ }^{3}$ See: 29 U.S.C. $\$ 626$ (d) (1994); and 42 U.S.C. $\$ 2000$ e5 (1994). Employees can elect to file with the federal, state, or local agency. In most circumstances, the agencies exercise concurrent jurisdiction so that claims are cross-filed among each agency. In other circumstances, the local agency stands on its own so that employees can have their claims investigated more than once. The City of Chicago's Human Rights Law is an example of the situation where an employee can pursue two claims simultaneously.

${ }^{4} I d$.

${ }^{5}$ One commentator, Michael Selmi, notes that the EEOC often informs the plaintiff of its intention to issue a nocause finding before doing so to afford the plaintiff an opportunity to request a right-to-sue notice. See: Michael Selmi, "The Value of the EEOC: Reexamining the Agency's Role in Employment Discrimination Law," 57 Ohio St. L.J. 1, 9 n. 35 (1996).
In the years 1992-2000, the EEOC resolved between 68,366 and 106,312 cases each year. ${ }^{6}$ The EEOC classifies each resolved case as either (1) a merit resolution (i.e., a settlement, a withdrawal with benefits, or finding of "cause") or (2) a non-merit resolution ("no cause" finding or administrative closing). With regard to merit resolutions during those years ('92-'00), the parties settled or "withdrew the case with benefits" in 7 percent to 13.2 percent of the cases, while EEOC found cause in fewer than 9 percent of the remaining cases each year (and only 2.3 percent in at least one year). ${ }^{8}$ Of the remaining non-merit resolutions, the EEOC found no reasonable cause in 48.1 percent to 61 percent of the cases during those years, and administratively closed 20.5 percent to 36.3 percent of the cases. ${ }^{9}$ Overall non-merit resolutions comprised 78.7 percent to 90.9 percent of the resolutions. ${ }^{10}$

I suggest three possible explanations for the large number of no-cause findings: (1) employees do not understand the law, (2) the EEOC is failing to find cause in cases with merit, or (3) employees are filing frivolous claims hoping for nuisance sertlements (that is, being paid a settlement to close the case regardless of its merit). ${ }^{11}$ Even if each explanation accounts for a third of those cases closed administratively or due to a no-cause finding, it would still mean that 26 percent to 30 percent of the cases filed in each of the last ten years were frivolous. In addition, discrimination investigators and defense lawyers contend that a substantial percentage of the merit resolutions include frivolous cases that were settled for nuisance values. ${ }^{12}$

${ }^{6}$ U.S. Equal Employment Opportunity Commission web site, http://www.eeoc.gov/stats/all.html (as viewed on January 13,2002$)$.

${ }^{7} \mathrm{Id}$.

${ }^{8} \mathrm{Id}$.

${ }^{9} I d$.

${ }^{10} I d$.

${ }^{11}$ David Sherwyn, J. Bruce Tracey, and Zev J. Eigen, "In Defense of Mandatory Arbitration of Employment Disputes: Saving the Baby, Tossing Out the Bath Water, and Constructing a New Sink in the Process," University of Pennsylvania Journal of Labor and Employment Law, Vol. 2, No. 1 (Spring 1999), pp. 73-150.

12 The author bases this statement on his seven years of experience as a management-side employment lawyer and on numerous conversations with other management-side lawyers, plaintiffs' lawyers, and investigators. 
Frivolous claims do not just injure lawabiding employers. An abundance of frivolous claims burdens the entire system and draws resources away from meritorious cases. Without sufficient resources to devote to the EEOC's everburgeoning caseload, it is likely that some legitimate claims--especially ones filed by employees with legitimate claims but who are not represented by attorneys-may slip through the cracks. The unfortunate result is that both employees and employers become cynical toward the system. This is a logical result when employees make legitimate claims that are not adequately redressed and employers who diligently comply with the federal and state discrimination laws are extorted.

The current system for resolving discrimination claims results in a system that provides perverse incentives for employees and employers with intent to deceive. With workloads continuing to increase at the same time that budgets remain relatively fixed, agencies are compelled to resolve claims in a more efficient manner by attempting to induce parties to settle. ${ }^{13}$ But when settlement becomes the overwhelming goal, the merits of each individual case tend to lose their significance, thereby creating an opportunity and incentive for employees to file frivolous claims. Employers, in turn, have an incentive to settle claims, even if they are frivolous, because of the high costs of the agencies' investigations and the even moreexorbitant costs of prospective litigation.

Responding to an agency's investigation may cost an employer, depending on the complexity and location of the case, between $\$ 2,500$ and $\$ 10,000 .{ }^{14}$ Litigating a case through trial costs the employer at least $\$ 50,000$ and could exceed $\$ 500,000 .{ }^{15}$ In most cases, the available damages are a fraction of the costs of defense, and there is

\footnotetext{
${ }^{13}$ Sherwyn et al., "Mandatory Arbitration," supra note 4, at 80-82.

${ }^{14}$ Telephone interviews with David Ritter, chair of the Labor and Employment Department at the law firm of Altheimer \& Grey, in Chicago, IL; and Peter Albrecht, partner at the law firm of Godfrey \& Kahn, in Madison, Wisconsin (March 12, 1998).

${ }^{15}$ Sherwyn et al., "Mandatory Arbitration," supra note 4, at 82 .
}

always the possibility of losing at trial. Defense lawyers believe that juries are unpredictable and fear that they are inclined to award large sums of money to the plaintiff in damages and attorneys fees that they may not deserve. ${ }^{16}$

"Bad actors" exploit the economic realities of the current system by using the costs of litigation to their benefit. Employers will have greater incentive to settle as long as the settlement figure is less than what it would cost to successfully defend a case before the EEOC or in federal or
When settlement becomes the overwhelming goal, the merits of each individual case lose their significance, thereby creating an incentive for employees to file frivolous claims.... state court. The result is what appears as a system of litigation extortion that can be euphemistically referred to as "de facto severance." 17 All the while, employees with legitimate claims may be forced to accept settlement offers representing but a small fraction of the real value of their cases because they cannot afford the time and money it takes to litigate.

Mediation. Instead of addressing the problems relating to litigation, the EEOC and others have sidestepped the issue by promoting mediation to resolve disputes. Mediation has great appeal because it is not, by definition, adversarial. Instead,

\footnotetext{
${ }^{16}$ By means of an anecdotal illustration, a team of defense lawyers conducted a mock jury trial before the actual trial of a case brought by a plaintiff who was diagnosed as a pathological liar by the defense-side's psychologist. Plaintiff had no supporting facts or witnesses to bolster her allegations of sexual harassment levied against a supervisor. Some of the mock-trial jurors awarded the plaintiff some damages not because they believed that she was sexually harassed, but rather because they felt sorry for her. Unbeknownst to the mock jury, awarding her even a modest sum may trigger a potentially exorbitant award of attorneys' fees. Suffice it to say that the frightening and somewhat surreal mockjury experience convinced the employer to settle the case.

${ }^{17}$ Sherwyn et al., "Mandatory Arbitration," supra note 4, at 82 (defining "de facto severance" as a process whereby employees file baseless discrimination charges because they know that their former employers are willing to pay a nominal amount of money to avoid the aggravation, costs, and losses of time, resources, and productivity that inevitably arise in defending such allegations).
} 
the parties, in theory, work together to come to mutually acceptable resolutions. While the theory of mediation is appealing, the reality leaves much to be desired.

In EEOC-sponsored mediations, the mediators do not examine the merits of the cases. Instead, the mediators simply attempt to reach a settlement. Another way to describe this situation is to simply ask: what will the employer pay and what will the employee accept to walk away? Inevitably, such a system results in employees tion, while truly wronged employees would not face unattainable barriers to receiving the damages to which they are entitled. Conversely, damage-seeking employees will be unable to leverage de facto severance payments and will receive little or nothing at all. Moreover, employers with bad intentions will be unable to force a plaintiffemployee to accept an otherwise less-than-deserved settlement. Instead, such employers will likely pay full damages (or closer to full damages than in some other settlement). Therefore, in comparison to alternative forms of dispute resolution, like mediation, and in comparison with traditional litigation, arbitration offers the parties savings in costs and time as well as incentives that may actually hinder discrimination and harassment in the workplace.

Mandatory arbitration's advantages have compelled many employers to extorting innocent employers and guilty employers exploiting employees who have suffered discrimination but are unable to obtain competent counsel.

Mediation does not resolve the issues associated with employment discrimination. Instead, it exacerbates the problems by institutionalizing de facto severance. Still, it does make sense to examine alternative methods to resolve disputes (rather than working through the courts). Such a system must provide a low-cost adjudication forum that discourages both employer discrimination and employee extortion. Mandatory arbitration may be the answer.

\section{The Arbitration Alternative}

Arbitrators adjudicate cases in a fraction of the time and for significantly less cost than when the parties go into litigation. ${ }^{18} \mathrm{~W}$ ith arbitration, wellmeaning employers would no longer be extorted into hasty settlements by the high costs of litiga-

\footnotetext{
${ }^{18}$ Compare: Ted Eisenberg and Elizabeth Hill, "Employment Arbitration and Litigation: An Empirical Comparison" (a working paper on file with the author) with Kathryn Van Wezel Stone, "Mandatory Arbitration of Individual Employment Rights: The Yellow Dog Contract of the 1990s," 73 Denv. U. L. Rev. 1017, 1039 (1996) (noting that the arbitrator's fees could easily exceed $\$ 1,000)$. See also: Sherwyn et al., "Mandatory Arbitration," supra note 4, at 132-133 (arguing that $\$ 1,000$ may be a paltry sum in comparison to the legal fees accrued during litigation).
} implement lawful mandatory-arbitration programs. Such programs are an effective means for employers to pool the risk of liability for being sued for unfounded claims and to resolve substantiated claims without fear of financial ruin or incurring bad publicity. Certainly, many employers in the United States that have already implemented such programs believe that the benefits of such risk-pooling far outweigh the disadvantages of mandatory arbitration (chiefly, that arbitrators' decisions cannot usually be appealed, and the lack of a guarantee that the arbitrator selected will fully understand the applicable laws). ${ }^{19}$

There are some, however, who argue that arbitration is not a suitable forum for resolving employment disputes. Many of these arguments are based on social policies that are beyond the scope of this article. The remaining arguments, which are addressed and confronted below, question the legality of mandatory arbitration pursuant to federal and state law.

\footnotetext{
${ }^{19}$ The American Arbitration Association (AAA) reports that more than 700 employers have mandatory-arbitration systems under which the AAA is designated as the agency to administer the program. That information was presented by the general counsel at a research conference on domestic and international arbitration sponsored by the Institute of Judicial Administration, at NYU Law School, September $20,2002$.
} 


\section{The Law of Mandatory Arbitration}

The lawfulness of arbitration of disputes arising out of Title VII of the Civil Rights Act of 1964 (as amended) ${ }^{20}$ the Age Discrimination in Employment Act (ADEA), ${ }^{21}$ and the Americans with Disabilities Act (ADA) ${ }^{22}$ has been the subject of at least five U.S. Supreme Court cases, ${ }^{23}$ as well as countless circuit-court opinions, district-court opinions, and law-review articles. ${ }^{24}$ For the most part, the debate has focused on four areas: (1) the role of the EEOC, (2) whether the Federal Arbitration Act (FAA) applies to employment contracts, (3) what constitutes a "fair" arbitration agreement, and (4) the effect of Section 118 of the Civil Rights Act of 1991.

Now, after ten years of debare, ${ }^{25}$ the first two issues have been resolved. Alternatively, the latter two issues remain unsettled despite the fact that there is a substantial amount of judicial authority on these topics. The section below explains the development of the law concerning each of those issues.

\section{The Change in the Law}

Prior to 1991 lawyers, judges, and scholars generally accepted that mandatory-arbitration agree- ments were unenforceable with regard to cases filed under federal anti-discrimination statutes. ${ }^{26}$ That position was based on Alexander v. GardnerDenver $\mathrm{Co}^{27}$ In that case, the U.S. Supreme Court held that an employee could proceed with a Title VII claim even after she suffered an adverse decision in a labor-arbitration award handed down pursuant to a collective-bargaining agreement. ${ }^{28}$ The lower courts extended this holding to the nonunion setting and, thus, for some years it seemed clear that mandatory-arbitration agreements were unenforceable. ${ }^{29}$ The court left open several questions, however. Two of the mostdebated issues concerned the role of the EEOC and the scope and applicability of the FAA. The Court finally resolved these issues in its EEOC $v$. Waffle House and Circuit City v. Adams decisions.

\section{The Role of the EEOC}

As explained above, employees must file charges of discrimination with the EEOC before filing lawsuits in federal court. After its investigation, the EEOC can attempt to settle the case, issue a right-to-sue letter, or sue on behalf of the plaintiff. The advent of pre-dispute mandatory arbitration has led to these three questions: (1) Can

\footnotetext{
${ }^{20} 42$ U.S.C. $\$ \$ 2000 \mathrm{e}-2000 \mathrm{e} 17$ (1994).

${ }^{21} 29$ U.S.C. $\$ \$ 621-634$ (1994).

2242 U.S.C. $\$ \$ 12101-12134$ (1994).

${ }^{23}$ See: Alexander v. Gardner-Denver Co., 415 U.S. 36 (1974); Gilmer v. Johnson-Interstate Corp., 500 U.S. 20 (1991); Wright v. Universal Maritime Service Corp., et. al., 525 U.S. 70 (1998); Circuit City v. Adams, 532 U.S. 105 (2001); and EEOC v. Waffle House, Inc., 121 S. Ct. 1401 (2001) (cert. granted).
}

${ }^{24}$ See, for example: Samuel Estreicher, 16 Ohio St. J. on Disp. Resol. 559 (2001); Delphene Hardin, "Sacrificing Statutory Rights on the Altar of Pre-dispute Employment Agreements Mandating Arbitration," 28 Cap. U.L. Rev. 455 (2000); Richard A. Bales, "Compulsory Employment Arbitration and the EEOC," 27 Pepp. L. Rev. 1 (1999); and Samuel Estreicher, "Predispute Agreements to Arbitrate Statutory Employment Claims," 72 N.Y.U. L. Rev. 1344 (1997).

${ }^{25}$ Sherwyn et al., "Mandatory Arbitration," supra note 4, at n. 16. See also: David Sherwyn, "Because It Takes Two: Why Post-dispute Voluntary Arbitration Programs Will Fail to Fix the Problems Associated with Employee Discriminationlaw Arbitration," forthcoming, Berkeley Journal of Employment and Labor Law.

${ }^{26}$ See: Alexander v. Gardner-Denver Co., 415 U.S. 36, 47 (1-974) ("There is no suggestion in [Title VII] that a prior arbitral decision either forecloses an individual's right to sue or divests federal courts of jurisdiction."); Utley $v$. Goldman Sachs of Co., 883 F.2d 184, 187 (1 st Cir. 1989) (holding that Title VII claims are nonarbitrable in nonunion employment setting); and Swenson v. Management Recruiters Int'l, Inc., 872 F.2d 264 (8th Cir. 1989) (distinguishing commercial from civil rights disputes in terms of mandatory arbitration).

27415 U.S. 36 (1974).

${ }^{28}$ Id. at 59-60 (noting that "the federal policy-favoring arbitration of labor disputes and the federal policy against discriminatory employment practices can best be accommodated by permitting an employee to pursue fully both his remedy under the grievance-arbitration clause of a collective-bargaining agreement and his cause of action under Title VII").

${ }^{29}$ See, for example: McDonald v. City of West Branch, Michigan, 466 U.S. 284 (1984). 
the employees still file claims with the EEOC?, (2) Can the EEOC still file lawsuits on behalf of employees?, and (3) If so, may the agency seek money damages, or is it limited to seeking injunctive relief?

The first question was definitively answered by the Gilmer court, which stated: "An individual ADEA claimant subject to an arbitration agreement will still be free to file a charge with the EEOC, even though the claimant is not able to institute a private judicial action. Indeed, Gilmer filed a charge with the EEOC in this case." ${ }^{30}$ The U.S. Supreme Court answered the second question when, in response to Gilmer's contention that arbitration was an inappropriate forum for class actions and equitable relief, it stated: "arbitration agreements will not preclude the EEOC from bringing actions seeking class-wide and equitable relief." ${ }^{31}$ Refuting this argument did not, however, end the controversy regarding the role of the EEOC. Instead, it created the third question. In EEOC v. Kidder, Peabody \& Co. ${ }^{32}$ and Merrill, Lynch, Pierce, Fenner and Smith, Inc. v. Nixon ${ }^{33}$ the Second and Eighth Circuits, relying on Gilmer, held that the EEOC could seek injunctive relief only. In contrast, in EEOC $v$. Franks Nursery, Inc., ${ }^{34}$ the Court of Appeals for the Sixth Circuit held that an arbitration agreement does not prevent the EEOC from pursuing an action for monetary damages. In EEOC $v$. Waffle House, ${ }^{35}$ the U.S. Supreme Court resolved the question.

In Waffle House the court held that the EEOC has the right to seek monetary relief for the plaintiffs on whose behalf it sued, and based its holding on two grounds: (1) Gilmer did not limit the EEOC to seeking injunctive relief, it just stated that the EEOC could pursue such cases; and (2) limiting the EEOC to injunctive relief has no support in statutory law or public policy. Under the law, the EEOC has the right to en-

\footnotetext{
${ }^{30} \mathrm{Id}$. at 28.

${ }^{31}$ Id. at 32.

32156 F.3d 298 (2nd Cir. 1998).

${ }^{33} 210$ F.3d 814 ( $8^{\text {th }}$ Cir. 2000).

${ }^{34} 177$ F.2d 448 (6 $6^{\text {th }}$ Cir. 1999).

${ }^{35} 122$ S. Ct. 754 (2002).
}

force the discrimination laws. One method of such enforcement is through litigation. If a court held that the EEOC could not sue for monetary damages, that holding would impair the agency's ability to enforce the law-given that most violations are settled by monetary payments. It is unlikely that employees who believe that they have been discriminated against would go through the pains of litigation just so that the EEOC could get an order preventing the employer from engaging in such conduct. Thus, preventing the EEOC from pursuing money damages would essentially allow an employer and employee to contract away the EEOC's right and obligation to enforce the law.

Although Waffle House represents a significant legal holding and resolved an important open question, the popular press has treated this holding as if it had much greater practical effect on employers than it actually does. In fact, the holding will have little or no effect on the vast majority of employers because the EEOC litigates a minuscule fraction of the discrimination charges it receives. For example, in the year 2000, the EEOC received just under 80,000 discrimination charges and filed lawsuits in only 291 cases (that's less than one-third of one percent of those filed). In that same year, private plaintiffs filed 21,032 cases. Thus, the EEOC accounted for less than 2 percent of all federal-court cases. ${ }^{36}$

Further, the cases litigated by the EEOC are not the type that mandatory arbitration was designed to address. Employers enact mandatoryarbitration policies to avoid the incentive for employees to file frivolous claims that lead employers to pay de facto severance. The Waffle House ruling will have no effect on those types of situations because the EEOC does not litigate garden-variety cases. Instead, the EEOC only litigates cases that involve a novel or unsettled area of law, or a class action. Those are the types of cases that belong in court because it is necessary for courts, not arbitrators, to develop the law by providing precedent for employers, employees, and arbitrators to follow.

\footnotetext{
${ }^{36}$ See: Waffle House, supra fn. 47.
} 


\section{The Federal Arbitration Act}

At the time of the enactment of the FAA in 1925, courts generally mistrusted arbitration as an adjudicative process and often refused to enforce parties' agreements to arbitrate in a variety of settings. ${ }^{37}$ Congress enacted the FAA to statutorily remedy that mistrust. In the broadest and most simple terms, the FAA reflects a "liberal federal policy favoring arbitration agreements. " ${ }^{8}$ Section 1 of the FAA, however, excludes from the act's coverage "contracts of employment of seamen, railroad employees, or any other class of workers engaged in foreign or interstate commerce. ${ }^{39}$ In Gilmer, the arbitration agreement at issue was held not to be an employment contract because the parties to the agreement were the New York Stock Exchange and Gilmer, not the "employer" and the "employee." ${ }^{* 0}$ Because the agreement that plaintiff Gilmer signed was not a condition of employment imposed on him directly by his employer, the court elected not to address the question of whether the term "engaged in for- eign or interstate commerce" of Section 1 of the FAA referred to all employees or to only those in the transportation industry. ${ }^{41}$ In Circuit City $v$. Adams the court held that the FAA's exception was limited to the transportation industry and that arbitration agreements in employment contracts were enforceable in other industries. ${ }^{42}$

The Circuit City decision received a fair share of publicity and rekindled the debate on arbitration. The decision's legal effect was limired, however, because it simply confirmed the current state of the law in nine of the twelve circuits. ${ }^{43}$ Moreover, despite the Supreme Court's holding, the Ninth Circuit, on remand, still refused to compel arbitration.

When the Ninth Circuit took up that case again, in what is being referred to as Circuit City $I I,{ }^{44}$ the court again refused to compel arbitration. This time the Ninth Circuit, relying on California contract law, held that the contract was unenforceable because it was both procedurally and substantively unconscionable. The court

${ }^{37}$ Kulukundi's Shipping Co. v. Amtorg Trading Corp., 126 F. 2d 978, 982-85 (2nd Cir. 1942) (offering an account of historical and judicial attitudes towards enforcement of arbitration agreements).

${ }^{38}$ Gilmer, 500 U.S. at 25, citing Moses H. Cone Memll Hosp. v. Mercury Constr. Corp., 460 U.S. 1, 24 (1983); see: supra note 5 .

39 9 U.S.C. $\$ 1$ (1994). The statute in its entirety provides: "Maritime transactions," as herein defined, mean charter parties, bills of lading of water carriers, agreements relating to wharfage, supplies furnished vessels or repairs to vessels, collisions, or any other matters in foreign commerce which, if the subject of controversy, would be embraced within admiralty jurisdiction; "commerce," as herein defined, means commerce among the several States or with foreign nations, or in any Territory of the United States or in the District of Columbia, or between any such Territory and another, or between any such Territory and any State or foreign nation, or between the District of Columbia and any State or Territory or foreign nation, but nothing herein contained shall apply to contracts of employment of seamen, railroad employees, or any other class of workers engaged in foreign or interstate commerce.

${ }^{40}$ Gilmer, 500 U.S. at $25 \mathrm{n}$. 2. This minor detail spawned hundreds of lawsuits over the past decade and cost litigants millions of dollars.

${ }^{41}$ See: id. at 25 n. 2 . The court noted: Section 1 of the FAA provides that "nothing herein contained shall apply to contracts of employment of seamen, railroad employees, or any other class of workers engaged in foreign or interstate commerce." 9 U.S.C. $\$ 1$. Several amici curiae in support of Gilmer argue that that section excludes from the coverage of the FAA all "contracts of employment." Gilmer, however, did not raise the issue in the courts below; it was not addressed there; and it was not among the questions presented in the petition for certiorari. In any event, it would be inappropriate to address the scope of the $\$ 1$ exclusion because the arbitration clause being enforced here is not contained in a contract of employment. The FAA requires that the arbitration clause being enforced be in writing. See 9 U.S.C. $\$ \$ 2,3$. The record before us does not show, and the parties do not contend, that Gilmer's employment agreement with Interstate contained a written arbitration clause. Rather, the arbitration clause at issue is in Gilmer's securities registration application, which is a contract with the securities exchanges, not with Interstate. The lower courts addressing the issue uniformly have concluded that the exclusionary clause in $\$ 1$ of the FAA is inapplicable to arbitration clauses contained in such registration applications (citations omitted). Unlike the dissent (citation omitted), we choose to follow the plain language of the FAA and the weight of authority, and we therefore hold that $\$ 1$ 's exclusionary clause does not apply to Gilmer's arbitration agreement. Consequently, we leave for another day the issue raised by amici curiae.

${ }^{42}$ Circuit City v. Adams, 532 U.S. 105 (2001).

${ }^{43}$ Two Circuits had not ruled on the issue while the Ninth Circuit was an outlier.

${ }^{44}$ Circuit City Stores, Inc., v. Adams, 279 F. $3^{\text {rd }} 889$ (9 $9^{\text {th }}$ Cir. 2002). Hereafter, "Circuit City II." 
explained that it assesses procedural unconscionability by considering the "equilibrium between the parties and the extent to which the contract clearly discloses its terms. ${ }^{" 45}$ The court then stated that it determined substantive unconscionability by deciding "whether the terms of the contract are unduly harsh." ${ }^{46}$ In Circuit City II the court held that the arbitration agreement was both procedurally and substantively unconscionable. The section below both explains and critically examines the rationale behind the court's determinations.

A bad deal. The key factor in the court's determination that the Circuit City agreement was procedurally unconscionable is the fact that the company offered the contract, as a condition of employment, on a take-it-or-leave-it basis. According to the court, because Circuit City had considerably more bargaining power than did its employees, and because the employees could not modify the agreement in any way, the agreement was a contract of adhesion and, thus, unconscionable. The Circuit City II court also held that the arbitration agreement itself was substantively unconscionable. The agreement did, in fact, have a number of problems. Specifically, the agreement: (1) limited the available damages, (2) limited the statute of limitations, (3) required the employees to pay a portion of the arbitration fees, and-most tellingly (4) did not prevent the $\mathrm{em}$ ployer from bringing an action in court-yet it prevented employees from doing so.

The first two reasons for finding the Circuit City agreement unconscionable are both rational and easy to correct. It simply makes no sense to allow employers and employees to sign away their rights to collect damages or to revise the statute of limitations. The reason for arbitration is to avoid the costs, delays, and perverse incentives associated with litigation-but in so doing it should not take the teeth out of the law. Reducing the damages and revising the statute of limitations does, indeed, take the teeth out of the law by making it difficult and less desirable for employees to pursue their claims under the law.

The third issue--who pays the cost of arbitration?-is more complex, but still easy to cor-

$$
\begin{aligned}
& { }^{45} I d . \\
& { }^{46} I d .
\end{aligned}
$$

rect. The issue is complicated because some commentators have raised concerns that arbitrators may be corrupted if the employer pays the entire cost. To support this argument, commentators focus on the fact that employers will often contract with the American Arbitration Association or another alternative-dispute-resolution (ADR) provider. The argument is that such organizations will be reluctant to find against the employer if it is paying the full cost. Yet that argument fails for two reasons. First, ADR providers simply cre-

\section{The reason for arbitration is to avoid the costs, delays, and perverse incentives asso- ciated with litigation-but in so doing it should not take the teeth out of the law.}

ate a panel of arbitrators from which the lawyers on each side choose. A plaintiff's lawyer will never choose an arbitrator who is influenced by the fact that the employer is paying the entire cost. Second, the ADR organization does not care who pays, as long as the employer contracts with that organization. Thus, if the organization really is corrupt, it will support its client, the employer, regardless of who pays. Accordingly, if courts want to protect employees from corrupt $\mathrm{ADRs},{ }^{47}$ then the courts need to prohibit employers from contracting with just one or two organizations and, instead, require that arbitration agreements allow multiple ADR organizations to submit panels to the parties. I could find no case that requires such a clause. Moreover, that research did not uncover any case where a court refused to enforce an arbitration agreement because the employer agreed to pay the entire cost of arbitration.

Conversely, there are a number of cases where courts denied a motion to compel arbitration because the employee had to pay the costs. In one of the lead cases on this issue, Cole v. Burns Intern. Sec. Services, ${ }^{48}$ the court found it to be

\footnotetext{
${ }^{47}$ There is no evidence to support the proposition that any of the organizations are corrupt or that employees need protection from them.

${ }^{48} 105$ F.3d. 1465 (D.C. Cir. 1997).
} 
"unreasonable" for the employee to share the cost of the arbitrator that could be as much as $\$ 1,000$ per day. The court did not, however, refuse to compel arbitration. Instead, it simply "blue penciled"49 $^{\text {"49 }}$ the agreement by shifting all the costs to the employer. The majority of courts have not, however, followed such a procedure. Instead, most courts will enforce an arbitration agreement even if it forces the employee to pay some portion of the adjudication-process cost. ${ }^{50}$ For employers, the cost issue is easy to sum up: (1) ensure the enforceability by paying all costs, or (2) require employees to share in costs and hope the court will uphold the agreement. Indeed, in most cases the court will.

Failed mutuality. The fourth issue raised by Circuit City II was that, under the agreement, employees could not litigate disputes with the employer in court, but employers could bring a court action against its employees. This lack of mutuality is the basis on which a number of courts refuse to compel arbitration. ${ }^{51} \mathrm{On}$ its face, requiring mutuality makes sense. Why should an employer be allowed to use the courts while an employee cannot? One answer is that the two sides pursue different claims that provide different types of relief. Employees pursue discrimination, contract, and tort claims to obtain back pay, reinstatement, attorney's fees, and punitive and compensatory damages. Arbitrators can award those types of damages. Employers' claims, however, often consist of enforcing non-competition or trade-secret agreements. In those cases, the employer needs a court to immediately grant an injunction to prevent the employee from causing irreparable harm by violating such an agreement. Arbitration is not designed to provide such immediate relief. If courts insist on mutuality, arbitration may be inappropriate for employers that need to enforce trade-secret or noncompetition agreements.

\footnotetext{
${ }^{49}$ A court "blue pencils" a contract when it deletes or alters the objectionable clause and then enforces the contract.

${ }^{50}$ Michael H. LeRoy and Peter Feuille, "The Evergreen Tree of Compulsory Arbitration? Where Cost is an Unlawful Barrier to Private Dispute Resolution" (forthcoming, UCLA Law Review).

${ }^{51}$ The court based its conclusions on Armendariz v. Foundation Health Pyschcare Services, Inc., 24 Cal. $4^{\text {th }} 83$ (Cal. 2000).
}

Circuit City II is a difficult case to interpret because the court's ruling criticizes the company's arbitration agreement for at least five different reasons and then does not state which of those reasons are determinative. In other words, the court failed to state whether it would have enforced the agreement if any of the issues it identified had been addressed satisfactorily. Two months later, however, the Ninth Circuit did provide some guidance when it enforced an arbitration agreement in Circuit City Stores v. Ahmed. ${ }^{52}$ In this case the court held that the agreement was not "procedurally unconscionable" because the company did not "require" the employee to sign the pre-dispute agreement. Instead, the employee could opt out of the arbitration program during the first 30 days of employment. Employees who did not opt out were covered by the policy. Unfortunately, this opinion does not state whether this particular Circuit City arbitration agreement mirrored the one at issue in Circuit City II. According to those familiar with the case and subsequent Ninth Circuit cases, however, the agreements in Ahmed and Circuit City II were substantially the same. Thus, the Ninth Circuit held that a substantively unconscionable agreement is enforceable as long as it is not procedurally unconscionable. The Ninth Circuit affirmed and clarified this holding three months later in Circuit City v. Najd. ${ }^{53}$ In Najd the Ninth Circuit stated that the agreements in Circuit City II and Abmed (and presumably Najd) were "materially identical." Thus, the Ninth Circuit's holding is clear: substantively unconscionable agreements are enforceable as long as they are not procedurally unconscionable. That is, employees may choose to agree to an "unfair" arbitration agreement like the one at issue in Circuit City II, but they cannot be forced into such an inequitable agreement.

\section{Section 118 of the Civil Rights Act of 1991}

Section 118 of the Civil Rights Act of 1991 states: "[w] here appropriate and to the extent authorized by law, the use of alternative dispute resolution including....arbitration, is encouraged to

\footnotetext{
${ }^{52} 283$ F.3d 1198 (9 $9^{\text {th }}$ Cir. 2002).

${ }^{53} 294$ F.3d. 1104 (9 $9^{\text {th }}$ Cir. 2002).
} 
resolve disputes arising under [Title VII and the ADA]." 54 In Duffield the Ninth Circuit held that this language evidenced a congressional intent to probibit mandatory arbitration and thus arbitration agreements did not preclude an employee from filing a Title VII or ADA discrimination lawsuit in federal court (Section 118 is mirrored in the ADA). ${ }^{55}$ Every other circuit to rule on this issue rejected this position. ${ }^{56}$ On September 3, 2002, the Ninth Circuit settled the Duffield question, for now. In EEOC v. Luce, Forward, Hamilton \& Scripps ${ }^{57}$ a panel of three Ninth Circuit judges held that after Circuit City, Duffield was no longer good law. Thus, district courts in the Ninth Circuit can no longer refuse to compel arbitration based on Section 118 of the Civil Rights Act of 1991. This does not mean, of course, that the issue is resolved once and for all. The EEOC will ask either: (1) the entire set of Ninth Circuit judges to review the case, or (2) the U.S. Supreme Court to resolve the issue. If both the Ninth Circuit and the Supreme Court refuse the request, the issue will be over. If either one accepts the case, there will be more litigation. For now, however, the Section 118 issue is resolved.

\section{The Law of the Ninth Circuit}

Under the Abmed and Najd holdings, unconscionable pre-dispute agreements are enforceable so long as they are not offered on a take-it-or-leaveit basis. Employee-rights advocates should be concerned about those decisions. Enforcing a substantively unconscionable pre-dispute arbitration agreement simply because signing it was optional at the time of hire is, put simply, bad law. Professor Sam Estreicher contends that the beginning of an employment relationship is similar to the

\footnotetext{
${ }_{54}^{4}$ Pub. L. No. 102-166, $\$ 118,105$ Stat. 1071, 1081 (1991) (codified in scattered sections of 2 U.S.C., 29 U.S.C. and 42 U.S.C.).

55 144 F.3d 1182, 1185 (9th Cir. 1998).

56 See: Rosenberg v. Merrill Lynch, Pierce, Fenner Smith, Inc., 170 F.3d 1 (1st Cir. 1999); Desiderio v. NASD, 191 F.3d 198 (2nd Cir. 1999); Seus v. John Nuveen \& Co., 146 F.3d 175 (3rd Cir. 1998); Hooters of America, Inc. v. Philips, 173 F.3d 933 (4th Cir. 1999); Mouton v. Metropolitan Life Ins. Co., 147 F.3d 453 (5th Cir. 1998); and Koveleski v. SBC Capital Markets, Inc., 167 F.3d 361 (7th Cir. 1999).

${ }^{57} 2002$ U.S. App. LEXIS 18043 (Ninth Cir. 2002).
}

beginning of a love affair between two people. Both sides, according to Estreicher, want this relationship to last, neither anticipates any problems, and both are willing to make seemingly small sacrifices to get the relationship off on the right foot. Accordingly, Estreicher predicts that most employees will sign anything at the time of hire. ${ }^{58}$ Employers therefore have a perverse incentive to create unfair, one-sided agreements

\section{Enforcing a substantively unconscion- able pre-dispute arbitration agree- ment simply because signing it was optional at the time of hire is, put simply, bad law.}

with opt-out provisions. Such agreements: (1) will satisfy the Ninth Circuit's standards, and (2) bind employees because it is unlikely that new hires will assertively opt out of such agreements (neither Najd nor Ahmed opted out, for example).

In addition to creating a perverse incentive, those holdings invite a question. The question can be framed as follows: If courts will enforce a substantively unconscionable agreement as long as it is not procedurally unconscionable, will the courts enforce a procedurally unconscionable agreement as long as it is not substantively unconscionable? In other words, can a take-it-orleave-it offer (which the Ninth Circuit deemed procedurally unconscionable) be enforceable if the agreement is not substantively unconscionable? Based on how the Ahmed and Najd courts applied Circuit City IIs holding that: "Under California law, a contract is unenforceable if both procedurally and substantively unconscionable," 59 it seems clear that an agreement might be enforceable if it is procedurally or substantively unconscionable, but not if it is procedur-

\footnotetext{
${ }^{58}$ Professor Estreicher made those comments at the first annual Hospitality Industry Labor and Employment Law Round Table, held at Cornell University's School of Hotel Administration and sponsored by the Center for Hospitality Research (May 5-6, 2002).

${ }^{59}$ Circuit City II at 893 (emphasis added).
} 




David Sherwyn, J.D., is an assistant professor of law at the Cornell University School of Hotel Administration (dss18@cornell.edu).

(c) 2002, Cornell University ally and substantively unconscionable. Thus, employers can require employees to sign arbitration agreements so long as the agreements are "fair," or enforce unfair agreements so long as the employees can opt out.

\section{The Meaning of "Fair"}

Outside of the Ninth Circuit the general rule is that mandatory arbitration agreements are legal as long as they are "fair." Despite the fact that neither the U.S. Congress nor the Supreme Court has defined what constitutes a "fair" arbitration agreement, and despite the fact that there are those of the mind that there is no such thing as a "fair" arbitration agreement, enough authority exists on the issue to propose some reliable and comprehensive guidelines. In examining fairness, Gilmer and its progeny focus on the following seven issues: (1) who pays the costs of arbitration, (2) the procedures for selecting the arbitrator, (3) mutuality, (4) whether the employee entered into the agreement knowingly and voluntarily, (5) available damages, (6) the method of delivering opinions, and (7) discovery. ${ }^{60}$ As discussed above, the Circuit City II court examined the first four issues and set standards for each. Those standards are not, however, the law outside of the Ninth Circuit. Still, with respect to the first three issues, one can ensure enforceability if the employer pays the entire cost of the arbitration, both parties must have a substantial role in selecting the arbitrator, and both sides agree that arbitration will be the exclusive forum for both parties.

With respect to take-it-or-leave-it offers, only the Ninth Circuit holds such terms to be unconscionable. In the rest of the country, arbitration agreements are enforceable so long as they clearly describe the terms of the agreement (e.g., the agreements must state that discrimination claims are covered and that the document being signed is a binding legal contract) and are not hidden in an employee handbook or some other long and

\footnotetext{
${ }^{60}$ The Supreme Court in Gilmer reiterated the so-called savings clause of $\$ 2$ of the FAA (arbitration agreements are enforceable "save upon such grounds as exist at law or in equity for the revocation of any contract"). See: Gilmer, 500 U.S. at 33; and 9 U.S.C. $\$ 2$ (1994). The Court also stated that " $[t]$ here is no indication in this case, however, that Gilmer, an experienced businessman, was coerced or defrauded into agreeing to the arbitration clause in his registration application." Id.
}

intimidating document. ${ }^{61}$ This is the case even if the arbitration is offered on a take-it-or-leave-it basis.

There is conflicting authority on how (and whether) arbitration agreements may limit damages available to prevailing parties. Case law and a mass of scholarly work support the argument that arbitration agreements must permit an arbitrator to award the same damages that would be available to parties had they prevailed in court. ${ }^{62}$ Alternatively, there are cases holding and others implying that arbitration agreements are enforceable even if they limit damages to less than what the prevailing parties might be entitled to had their case been heard in court. ${ }^{63}$ Last, arbitration agreements should provide for written opinions, and agreements must allow for at least some discovery, even if it is limited.

\section{What This Means for Employers}

Mandatory arbitration is an effective way to reduce the costs of litigation. While the law is not completely settled, employers in almost all jurisdictions can draft enforceable arbitration policies. Employers interested in pursuing such an option should contact counselors who have experience in drafting and litigating the enforceability of arbitration agreements.

${ }^{61}$ See, for example: Trumbull v. Century Mktg. Corp., $12 \mathrm{~F}$. Supp. 2d 683 (N.D. Ohio 1988) (denying enforcement where the arbitration-of-claims policy was found on less than two pages in the middle of a 60 -page employee handbook).

${ }^{62} \mathrm{See}$, for example: Graham Oil Co. v. Arco Products Co. 43 F.3d 1244 (9th Cir. 1994). Additionally, in accordance with the National Rules for the Resolution of Employment Disputes, the arbitrator may grant any remedy or relief that the arbitrator deems just and equitable, including any remedy or relief that would be available to the parties had the matter been heard in court. This authority includes the right to award compensatory and exemplary (or punitive) damages and other remedies to the extent those remedies would be available under applicable law in court. See also: JAMS, Policy on Employment Arbitration Minimum Standards of Procedural Fairness, at www.jamsadr.com/employment Arb_min_stds.asp\#two (as viewed on November 11, 2001); Cole v. Burns Int'l Sec. Servs., 105 F.3d 1465 (D.C. Cir. 1997); and Armendariz v. Foundation Health Psychare Serv., Inc., 24 Cal. 4th 83, 103 (Cal. 2000).

${ }^{63}$ See: Degaetano v. Smith Barney, Inc., 70 Fair Empl. Prac. Case. (BNA) 401 (S.D.N.Y. Feb. 5, 1996) (upholding an arbitration agreement that prevented the arbitrators from awarding punitive damages or injunctive relief of any kind); and Kinnebrew v. Gulf Insurance Co., 67 Fair Empl. Prac. Cas. (BNA) 189 (N.D. Tex. Nov. 28, 1994). 